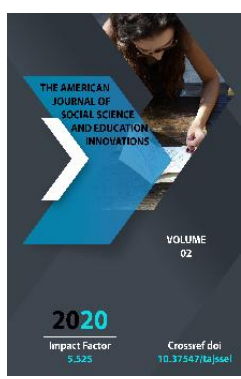

\section{Army And Military Education In The Republic Of Bukhara} (1920-1924)

\author{
Rozimova Yorqinoy Yuldashevna \\ Candidate Of Historical Sciences, Academy Of The Armed Forces Of The Republic Of \\ Uzbekistan Teacher Of The Department Of Humanities, Uzbekistan
}

Journal Website: http://usajournalshub.c om/index,php/tajssei

Copyright: Original content from this work may be used under the terms of the creative commons attributes 4.0 licence.

\title{
ABSTRACT
}

The Republic of Uzbekistan has a rich history. The contribution of our brave and courageous ancestors in the military sphere is significant in achieving the level of the most important partner of the state and the army in all spheres, as well as strengthening equal diplomatic and political relations with the developed countries of the world. Therefore, this article provides information on the development of the army and military education in the Republic of Bukhara in 1920-1924.

\section{KEYWORDS}

Turkestan, Bukhara, army, military education, Minister of Defense, Commander-in-Chief, Red Army, cavalry, infantry, tactics, military management, military topography.

\section{INTRODUCTION}

It should be noted that after the coup d'etat of 1917, the Turkic peoples carried out a number of organizational work to establish their national statehood, and the establishment of a national army in the system of public administration was also emphasized. To this end, the All-Turkestan Provincial Congress was held in Orenburg from December 5 to 13,1917, in which Alimkhan Ermak was appointed Minister of Defense. At 
the All-Khorezm Congress in February, Hasan oglu was appointed Minister of Defense, Mirsharof oglu was appointed Commander-inChief, and at the All-Bukhara People's Congress convened on 6 October this year, Abdulhamid Arif was appointed Minister of Defense.

The statesman Fayzulla Khodjaev said that in order to ensure the peace of the Bukhara People's Soviet Republic, it is necessary to have its own army in the country, the police and security agencies. "We will create a technically armed, disciplined and powerful Uzbek Red Army to repel the attacks of the enemies of Uzbekistan, including the entire Soviet socialist republics," he said. To this end, on November 3, 1920, a temporary militarypolitical agreement was signed between the RSFSR and the Bukhara Soviet Socialist Republic. According to the agreement, the RSFSR undertook to provide the 10,000strong army of the Bukhara Soviet Socialist Republic with all necessary weapons and clothing, and sent military specialists, teachers and instructors.

Special uniforms were developed for the Bukhara army, and rank marks were developed to determine the composition of commanders.

\section{MATERIALS AND METHODS}

Particular attention was paid to the provision of the army with military personnel, and the first Bukhara combined military command course named after the Council of People's Ministers was organized in Bukhara. The staff unit of the course was formed at the level of the regiment staff unit. As of January 1, 1920, there were 1,486 students in these courses, of whom only 96 were Muslims. The courses were attended primarily by members of the
Bolshevik Party and government officials. At the same time, servicemen of the army of the former Emir of Bukhara were also recruited, who first underwent a special examination, and after enrollment were involved in intensive political training. Cavalry and infantry machine gun units were organized in the courses, and the training period was set at 4 months.

The main subjects taught are tactics, military topography, fortification (military engineering fortifications), shooting training and machine gun work, military management, hippology and equestrian theory, communication, military hygiene, Russian language, mathematics, geography, natural sciences, production organization, Uzbek language. which was. In 1922, the training of secondary medical staff was organized at the course. The division staff was designated as 30 listeners. The study period was set at 1 year and 2 months. Laboratories for 20 beds were set up in the military units of the Chorjoi garrison for practical training.

\section{RESULT AND DISCUSSION}

In order to improve the educational process, the "Status of the Pedagogical Council of Military Educational Institutions" was developed. In order to develop military science, study the achievements in all areas of modern martial arts, define and improve military tasks, a military research center was established under the course, which includes sections on tactics, cavalry, artillery, communications, politics, history, technology, geography, medicine and oriental studies. was determined to go. The units of the center were shown to be in large garrisons.

At the initiative of Fayzulla Khodjaev, the study of military labor education for young 
people was introduced in Bukhara. In 1923, a military labor school was opened in Bukhara. The school was subordinated to the Bukhara Red Army Commander. The student body was set at 100 people. It was determined that the orphans of farmers and workers had the privilege of enrollment. When there were vacancies, the children of union committee members as well as the children of the military could be admitted to school. There is no charge for tuition. Young children were not involved in any entrance exam upon admission to 1st grade. Admission to the next grades is based on the subjects taught in the previous class.

No documents were attached to the school admission request, only a certificate from the local executive committee and the police stating that there was a parent or provider. Recipients are required to undergo a mandatory medical examination. Those unfit for military service and those unable to serve in the future were not admitted to the school. Classes are organized according to age and combined into routes. The companies, in turn, were divided into platoons, which were marked with a serial number, which had 30 men. The number of students in the classes should not exceed 25 people. The school taught military subjects in addition to general subjects.

Those who have successfully completed the courses and are qualified for military training have been assigned to the Bukhara Commanders' Course.

At the V Congress of All Bukhara People's Representatives held on September 18-20, 1924, the Bukhara People's Soviet Republic was transformed into the Bukhara Soviet Socialist Republic, as a result of which the democratic path of development was denied and forced into the socialist direction. At the end of November of this year, the Bukhara Soviet Socialist Republic was abolished and the Bukhara army and military education system were abolished as a result of national annexation by Uzbekistan as a result of national restrictions imposed by the Soviet state.

\section{CONCLUSION}

Based on the above information, the following can be concluded:

1. The courage of our brave ancestors in the formation of the army in the first half of the twentieth century, arming them and providing them with all the necessary supplies became the basis for the rapid development of the army and military education.

2. Through the systematization of military education, the military training of troops has been brought to a high level of combat readiness.

3. History itself has always proved that in a short historical period, an existing statehood can be abolished or a new state can emerge.

4. States with high military discipline and well-equipped armies have always been among the strongest, most powerful states.

5. Every state relies on its rich history and the experience of great personalities in building its army and developing military education. This shows that the state and the nation itself are not indifferent to history. 


\section{REFERENCES}

1. History of Uzbekistan 1917-1991 - T .: Members of the Public Council on Modern History of Uzbekistan at the Academy of Sciences (FA), the Institute of History of the Academy of Sciences, the Coordinating and Methodological Center for Modern History of Uzbekistan and leading scientists in higher education , -2019. -B.125-210.

2. Jo'raev N., Fayzullaev T. History of independent Uzbekistan. - $\mathrm{T}$.: Sharq Publishing and Printing Concern of the Academy of State and Social Construction under the President of the Republic of Uzbekistan, - 2000. - B. 74-77.

3. Qodirov A.R., Nosirov J.A. History of Uzbekistan / Textbook. - T .: Academy of the Armed Forces of the Republic of Uzbekistan, -2019. - B. 36-42.

4. Tursunboeva N. History of Uzbekistan. / Methodological manual.-T .: New century generation, -2014. - B. 233-245. 